by barnacles and molluses, the destruction of stored products by rodents, and hazards caused to aircraft by birds. It has been estimated that European countries alone lose $£ 400$ million annually through biodeterioration of goods such as timber, textiles, jet fuels, paint, metals and plastics. The figure must be very much higher than this for the whole world, because biodeterioration is an ever more serious problem in tropical countries. The loss of stored food products from spoilage, contamination and deterioration varies from one country to another, being worst in the developing countries, but over the world as a whole it is probably about 30 per cent. As the report of the US President's Science Advisory Committee on The World Food Problem, published last year, put it, "If only half of the estimated world loss of food grains was prevented, it would represent an additional 55 million tons or enough to make the diet of 500 million people in developing countries adequate in total calories". And the loss of food supplies is only part of the biodeterioration problem - a problem which is made worse by the interdisciplinary nature of the subject which leads to difficulties in communicating information.

The Biodeterioration Information Centre hopes to helf solve the problem by providing an information service to workers concerned with biodeterioration all over the world. The centre collects articles on the subject selected by specialists in more than 30 countries. Each item is indexed with appropriate keywords selected from a specially prepared thesaurus and is recorded in a punched card index system. All the accessions of the centre, which number 2,500 to 3,000 articles a year, are listed in a classified bibliography (IBBRIS) which is published quarterly. A photocopy service for inaccessible literature is operated and a question. answering service provides either IBBRIS accession numbers or, when available, author abstracts of articles in the collection. A further service is the publication of original and review papers in the International Biodeterioration Bulletin. Associated with the centre are two laboratories where research into microbiological deterioration is done. Current research projects include studies on the breakdown of cellulose by fungi, the growth of fungi in high temperatures and the detoxification of preservatives by fungi and bacteria.

\section{Not for Drinking}

WATER from the mains is not as pure as most people would like to think. This was clearly emphasized on March 8 during the afternoon technical sessions of the sixteenth annual general meeting of the Society for Water Treatment and Examination. In the rather spartan main hall of the College of Preceptors, Bloomsbury Square, the audience was told how living organisms ranging in size from viruses to beetles are contaminating water in Britain. Fortunately, most of the animals involved are not known to involve risk to human health, although infectious hepatitis-a faecally excreted virus-is transmitted by water. Dr S. F. B. Poynter, senior assistant bacteriologist to the Metropolitan Water Board, suggested that not only are large numbers of potentially pathogenic organisms excretedfor example, the three types of poliovirus, and adenoviruses-but it has been shown that existing methods of sewage treatment are ineffective inactivators of these viruses. A typical disinfectant, combined chloride in its various forms, is relatively useless as a virucidal agent. As a result, viruses are discharged in the effluents flowing into rivers and are then borne to water storage reservoirs. Trickling filters seem to be particularly inadequate, but a number of investigators have found that activated sludge treatment is more effective. During the discussion Mr R. W. Covill of the Lothian River Board, Edinburgh, said that he knew of a case of partially and unpurified sewage being used to irrigate crops of lettuces and strawberries, and suggested that there is a need for more stringent precautions in this connexion.

Animals in mains are also creating an increasing problem, which Mr I. C. Smalls and Mr G. F. Greaves of the Biology Division at the Water Research Association have investigated. According to a survey which they have undertaken, infesting animals may give rise to complaints by the appearance of individual animals at the tap, by discolouring the water with, for example, faecal pellets, or possibly by causing tastes and odours as a result of the decomposition of dead animals in the mains by bacteria, fungi and actinomycetes. Regular tap samplings of a Scottish supply yielded whole animals, such as Cyclops strenuus abyssorum, Chydorus sphaericus, Diaptomus sp. and Rotifera.

Asellus aquaticus grips tenaciously to nodular encrustations in mains, while some Nais sp. and some blood worms form protective tubes from organic detritus and rust particles attached to pipe walls. Other strains are able to produce resting stages in order to survive unfavourable conditions. According to Mr Smalls, underground supplies contain fewer species and smaller total numbers of organisms than supplies from the surface because underground water is less productive of organic matter on which the animals feed. Systemic flushing has been used as a control measure, either by itself to flush out free-swimming animals, or together with chemical dosing to remove more tenacious species.

\section{Degrees by Television}

THE planning committee of the Open University (which is the British Government's name for its proposed television university) has now outlined the pattern of the degrees which will form the core of the university's work when it begins in October 1970 or January 1971. Details of the courses will be left to the university staff to work out, but the basic system, which requires six credits for an ordinary degree and one year's work for each credit, has been put forward by the committee appointed six months ago under the chairmanship of Sir Peter Venables, Vice-Chancellor of the University of Birmingham (see Nature, 215, 1322; 1967). No formal academic qualifications will be required for entry and the normal minimum time for a degree will be four years. In exceptional circumstances, particular individuals might be allowed to qualify in a shorter time, but part-time students might well take longer than the minimum.

Four broad "lines"--science, technology, social science and arts-have been set out for degrees, but the maximum flexibility will be provided so that students can take courses from each line. Two credits in the first year foundation courses will normally be required 